\title{
The visual characteristics and quality of cultured gilthead seabream (Sparus aurata) in earthen ponds and net cages in Turkey
}

\section{Türkiye'de toprak havuzlarda ve ağ kafeslerde yetiştirilen çipura balığı'nın (Sparus aurata) görsel karakteristikleri ve kalitesi}

\author{
Gülgün F. Ünal Şengör ${ }^{1 *}$ • Zafer Ceylan ${ }^{2}$ • Sevan Gürün ${ }^{3}$ • Samet Kalkan ${ }^{4}$ • \\ Onnocan Hulyar ${ }^{5}$
}

\author{
1 İstanbul Üniversitesi, Su Bilimleri Fakültesi, Gıda Güvenliği Anabilim Dalı, İstanbul, Türkiye \\ 2 Van Yüzüncü Yı Üniversitesi, Turizm Fakültesi, Gastronomi ve Mutfak Sanatları Bölümü, Van, Türkiye \\ ${ }^{3}$ İstanbul Üniversitesi, Su Bilimleri Fakültesi, Deniz Biyolojisi Anabilim Dalı, İstanbul, Türkiye \\ ${ }^{4}$ Recep Tayyip Erdoğan Üniversitesi, Su Ürünleri Fakültesi, Deniz Biyolojisi Anabilim Dalı, Rize, Türkiye \\ 5 İstanbul Üniversitesi, Su Bilimleri Fakültesi, Deniz Biyolojisi Anabilim Dalı, İstanbul, Türkiye
}

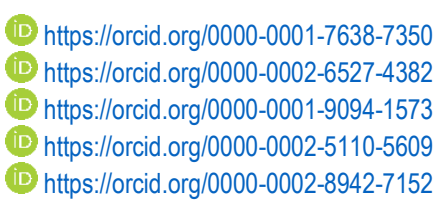

\section{How to cite this paper:}

Ünal Şengör, G.F., Ceylan, Z., Gürün, S., Kalkan, S. \& Hulyar, O. (2021). The visual characteristics and quality of cultured gilthead seabream (Sparus aurata) in earthen ponds and net cages in Turkey. Ege Journal of Fisheries and Aquatic Sciences, 38(3), 365-373. DOI:10.12714/egejfas.38.3.13

Abstract: The objective of this study is to investigate the quality differences and visual characteristics between cultured gilthead sea bream obtained from earthen ponds and net cage habitats. No significant differences from obtained in two different habitats are determined cultured gilthead sea bream in terms of chemical and microbiological quality. It has been determined that it is a safe food for consumption since it does not contain pathogenic microorganisms such as Escherichia coli and Salmonella spp. that negatively affect food safety. Visual quality differences are distinguished like the skin color, reddish color on the operculum cover, the head shape and the tail transparency from each other. Having unique sensorial characteristics fishes from two different habitats do offer valuable nutrient sources for consumers. Thanks to the controlled aquaculture conditions, safe production of cultured gilthead sea bream is carried out according to food safety in Turkey. Therefore owing to their delicious food source of cultured gilthead sea bream it is preferred for consumption in Turkey and all ower the world.

Keywords: Gilthead seabream, breeding, quality, visual characteristics, food safety

Öz: Bu çalışmanın amacı, toprak havuzlarda ve ağ kafeslerde yetiştirilen çipura balıkları arasındaki kalite farkııklarını ve görsel özelliklerini araştırmaktır. Her iki habitatda yetiştiriciliği yapılan çipura balıklarında kimyasal ve mikrobiyolojik kalite açısından önemli bir farklılık tespit edilmemiştir. Escherichia coli ve Salmonella spp. gibi gıda güvenliğini olumsuz yönde etkileyen patojen mikroorganizma içermemesi bakımından tüketim için güvenli gıda olduğu belirlenmiştir. Görsel kalite farkıııkları olan deri rengi, solungaç kapağı üzerindeki kırmızımsı renk, kafa şekli ve kuyruk şeffaflığı ile birbirinden ayırt edilmektedir. Toprak havuzlarda ve ağ kafeslerde yetiştirilen çipura balıkları, farklı duyusal özellikleri ile tüketiciler için değerli besin kaynaklarıdır. Türkiye'de yetiştiriciliği yapılan çipura balıklarının, kontrollü akvakültür koşulları sayesinde gıda güvenliğine uygun üretimi yapılmaktadır. Bu nedenle kültüre alınan çipura balıkları, lezzetli besin kaynağı olması nedeniyle hem ülkemizde hem de dünyada tercih edilen ve güvenle tüketilen önemli bir ticari türdür.

Anahtar kelimeler: Çipura, yetiştiricilik, kalite, görsel karakteristikler, gıda güvenliği

\section{INTRODUCTION}

Aquaculture is the only alternative to wild capture fishing able to satisfy the increasing consumer demand for sustainable production of safe seafood of the highest quality and nutritional value (Claret et al., 2016). The decrease in the sustainability of natural aquatic food sources due to adverse environmental conditions in the aquatic environment, overfishing, increase in the invasive fish population, etc. creates difficulties every day in the consumption of safe fisheries. Thanks to the successful production in fish farming all over the world, it is possible to meet the important animal protein needs for human nutrition. The gilthead seabream (Sparus aurata) is an economically cultured fish species and a rich protein food source. Turkey is one of the leading aquaculture producing countries for farmed gilthead sea bream and sea bass together with Greece, Italy, and Spain. López Ales (2018) explained that there are gilthead seabream productions in 20 different countries, where through the years, the total production of gilthead sea bream has been increasing, Turkey is the main producer with $72.000 \mathrm{t}(34.8 \%$ total production), Greece with $51.000 \mathrm{t}(24.6 \%)$, Egypt with $26.000 \mathrm{t}(12.6 \%)$ and Spain with $13.642 \mathrm{t}$ (6.6\%). Marine fish farming was started at the beginning of the 1990s in Turkey. Generally marine fish was mostly cultured in the Mediterranean region in net cages. Aquaculture production gradually increases day by day owing to the increasing consumption of farmed marine fish all over the world. Total aquaculture fishery production of Turkey is approximately 276.502 tons, of which 99.971 and 61.090 tons of sea bass 
and sea bream respectively (TurkStat, Fishery Statistics, 2017). Total aquaculture fishery production of Turkey is 314.537 tons of which 209.370 tons is cultured marine fish and 105.167 tons is freshwater fish farming. 76.680 tons of cultured marine fish is gilthead sea bream and 116.915 tons is sea bass. It's projected that the amount of cultured gilthead sea bream and sea bass production will reach a total of 402.951 tons. (Tagem, 2019). It is clear from the statistics and the projections provided by the Republic of Turkey Ministry of Agriculture and Forestry that aquaculture production increases steadily at a high pace. Today, some of the producers around Muğla province contribute to the national economy by breeding gilthead sea bream in earthen ponds that are not on land unsuitable for agriculture and they produce fish similar to wild fish in terms of sensory characteristics. Others of the fish farmers are farming gilthead seabream in net cages offshore. Over the past decade demand for freshly cultured gilthead seabream in Turkey and Europe has increased significantly due to flavor, texture, total quality, availability throughout the year, and cost efficiency to consumers. Gilthead seabream is one the most and increasingly preferred cultured fish species worldwide. Factors affecting the sensorial and microbiological quality of cultured fish may vary depending on features of fish species, cultivation conditions, fish feeding regime, practices during harvesting and post-harvesting (Caggiano, 2000). Excessive feeding of fish increases the microbial load by enzyme activities in their digestive systems. Therefore the shelf life of these types of fish is short. The sources of contamination are soil, water, weather, human, and tool devices. Papadopoulos et al. (2003) reported that based on sensory and microbiological analyses gutted sea bass have a shorter shelf life than ungutted specimens. If the soil which is the natural environment for many microorganisms, is contaminated especially by the sewage systems or feces there would be an increase in both the species and number of microorganisms. Similarly, water may become another source of microbial contamination unless a sanitary condition for farmed fish is provided. The amount of bacteria in the aquatic waters has a significant effect on fish quality. Pollution and the presence of sediment deposition indicate the existence of the pathogenetic bacteria in waters used for aquaculture fish production. Microorganisms may cause a pathogenetic impact responsible for the deteriorating quality of fish flesh. The most common pathogens in fish are Salmonella typhi, E. coli, Pseudomonas florescens, Aeromonas hydrophilla, Proteus vulgaris, Staphylococus aureus, Shigella spp. (Obasohan et al.,2010). Bacteria present on the fish are normally associated with those found in their natural environment and influenced by the season and the harvesting condition. The proportion of the initial population can easily be changed after the harvesting process depending on the ability of the bacteria to adapt to the new conditions (ICMSF, 1998). Live fish is normally considered to be sterile but microorganisms exist on the skin and gills and in the alimentary tract of live and newly caught fish in varying numbers. A normal range of $10^{2}-10^{7}$ $\mathrm{cfu} / \mathrm{cm}^{2}$ on the skin and between $10^{3}-10^{9} \mathrm{cfu} / \mathrm{g}$ in the gills and intestines have been observed (Liston, 1980). Spoilage bacteria are predominant on newly caught fish but some pathogenic bacteria could also be present in the skin, gills, or guts (Jha et al., 2010). To ensure sensorial and microbiological quality in cultured fish it is necessary to control environmental factors, take measures to prevent the contamination of seawater, and hygiene practices. If the fish are stressed and alive, the lactic acid level will be increased, therefore the $\mathrm{pH}$ value will decrease dramatically; in case of prolonged stress, all glycogen will be consumed, leading to a high level of $\mathrm{pH}$. Meantime psychrophile and psychotropic aerobic, gram-negative bacteria, usually living on the fish begin to multiply and cause the characteristic odors affecting sensorial quality (Caggiano, 2000).

There are some studies on quality evaluation of cultured gilthead sea bream (Kyrana et al., 1997; Alasalvar et al., 2002 a, b; Grigrakis et al., 2002; 2007; Lougovoisa et al., 2003; Beklevik et al., 2005; Kılınc et al., 2007; Alvarez et al., 2008; Yıldız et al., 2008a, Yıldız, 2008b; Attouchi and Sodak, 2010; Cardinal et al., 2011). However, the aim of this study was to determine quality parameters and visual characteristics of gilthead sea bream cultured in different habitats.

\section{MATERIAL AND METHODS}

Gilthead seabream is cultivated in net cages and/or in earthen ponds by some of the producers around Muğla province in Turkey. In this research fresh gilthead seabream with an average weight of $300-350 \mathrm{~g}$ and an average length of 26-28 cm cultured in net cages (by Kılıc Deniz Co. in Bodrum, Turkey) and earthen ponds (by Association of Inland Aquaculture Farmer and Producers in Milas, Turkey) harvested in every two months were used. The fish were slaughtered by immersing in ice-cold water (hypothermia) and delivered to the laboratory (whole) within $12 \mathrm{~h}$ after harvesting, packed in separate thermo-insulated polystyrene boxes with ice. Figure 1 shows cultured gilthead sea bream. The photo on the left side represents in net cage cultured fish (a) and the right side represents farmed fish in earthen ponds (b).

\section{Physico-chemical analyses}

During analyzing period $\mathrm{pH}, \mathrm{TVB}-\mathrm{N}$, and $\mathrm{NH}_{3}-\mathrm{N}$ analyzes were measured for both of the groups. $\mathrm{pH}$ values of fish flesh $(1: 10 \mathrm{v} / \mathrm{w})$ were measured with Thermo Scientific Model Orion Star A 214 (USA) pH meter. $\mathrm{NH}_{3}$ measurement of fish flesh was measured according to the ISE procedure by Pivarnik et al. (1998). To determine $\mathrm{NH}_{3}$ value of fish flesh, $5 \mathrm{~g}$ of flesh fish, $95 \mathrm{ml}$ pure water, and $2 \mathrm{ml}$ alkali ISA were homogenized for 2 minutes. After calibrating the Thermo Scientific Model Orion Star A 214 (USA) pH/ISE meter, $\mathrm{NH}_{3}$ measurement had been carried out. The results of $\mathrm{NH}_{3}$ were provided as $\mathrm{mg} / 100$ g. The method reported by Schormüller (1968) was used to determine TVB-N values of fish samples. MgO was added to the homogenized fish samples and then it was distilled. After distillation, distilled ammonia materials were titrated with 0.1 $\mathrm{N} \mathrm{NaOH}$. The results were explained as mg TVB-N/100 g muscle. 


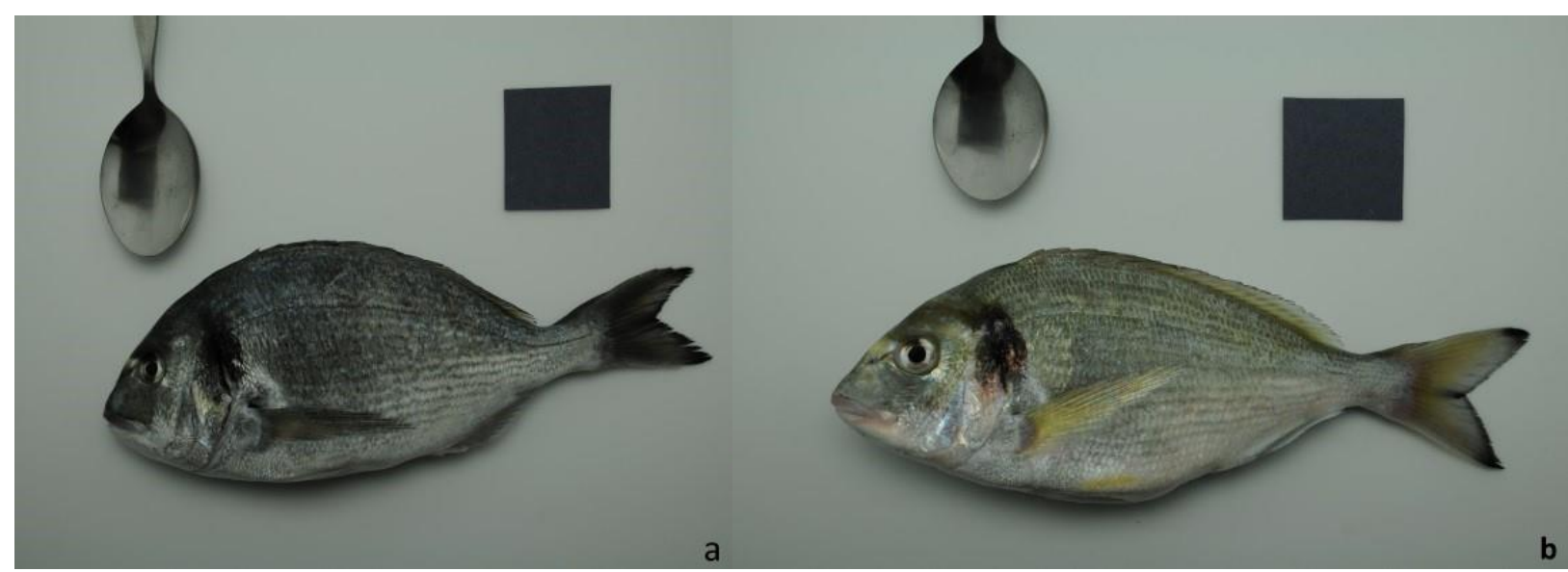

Figure 1. Cultured gilthead seabream (Sparus aurata) in net cage ${ }^{a}$ and in earthen ponds ${ }^{b}$ (Original photograph)

\section{Color measurement}

Color analyses were determined from each of five fish using Minolta CR-400 chromometer (Minolta Camera Co., Japan). The Minolta colorimeter was calibrated with a standard white plate (D65, $Y=93.9, x=0.3155, y=0.3319$ ) before each use $L^{*}, a^{*}, b^{*}$ values were measured under D65 illumination. By using five fish for each value $L^{*}, a^{*}, b^{*}$ values were measured three times from different spots on dorsal parts of skin, flesh, and operculum of each fish separately. Finally, the average value was calculated and recorded as result. $L^{*}$ value represents lightness from black to white between 0 and $100 a^{*}$ value represents color from red $(+)$ to green (-) and $b^{*}$ value represents color from yellow $(+)$ to blue $(-)$ in the color measurement of fish.

\section{Sensorial analyses}

\section{Raw and cooked fish samples}

The sensorial attributes of cooked fish were evaluated by a panel of ten experienced judges during each sampling period. Fish samples (100 $\mathrm{g}$ of fillets) were cooked individually in a steam cooker with a Pyrex lid (Raks Buharlım, Manisa, Turkey) which had been preheated to $100{ }^{\circ} \mathrm{C}$ for about 30 min until the internal temperature of each fillet reached $70{ }^{\circ} \mathrm{C}$ at the thickest part measured with a thermocouple probe. After reaching the desired internal temperature samples were immediately presented to the panelists (each panelist evaluating approximately $20 \mathrm{~g}$ of fish sample).

Panelists were asked to score the odor, taste, and texture of fish using a $0-10$ descriptive hedonic scale (Chang et al., 1998). The same panelists also scored QIM on the significant sensory parameters of raw fish using characteristic parameters and a scoring system from 0 to 3 demerit points (Huidobro et al., 2000).

\section{Microbiological analyses}

Total mesophilic aerobic bacteria count (TMABC) and yeast and mold count (TYMc) were determined as stated by Maturin and Peeler (1998) and Anonymous (2005) respectively. Each fish sample of $10 \mathrm{~g}$ was homogenized for $150 \mathrm{sec}$ in a stomacher (IU Instruments, Spain) with $90 \mathrm{ml}$ peptone water $(0.1 \%)$.Serial dilutions (from $10^{1}$ to $10^{4}$ ) were prepared for each sample obtained from obtaining different aquaculture habitats. Diluted samples were placed on plate count agar (PCA, Merck) and incubated at $35^{\circ} \mathrm{C}$ for $48 \mathrm{~h}$ to estimate TMABC count. Also dicloran rose bengal agar (DRBC, Merck) was used to estimate TYMc by incubating at $23^{\circ} \mathrm{C}$ for 5 days. Microbiological measurements were conducted on five whole fish samples and each measurement was repeated eight times resulted in sixteen $(n=16)$ measurements for each enumeration.

Detection of salmonella was determined as stated by Rall et al. (2005). During pre-enrichment $25 \mathrm{~g}$ of fish samples were homogenized with $225 \mathrm{ml}$ of buffered peptone broth in a stomacher for one minute. The fish samples were preenriched in buffered peptone broth which was incubated between 18 and $20 \mathrm{~h}$ at $35^{\circ} \mathrm{C}$. After pre-enrichment of the samples, selective enrichment was carried out, in this sense, $0.1 \mathrm{ml}$ (approximately) of the pre-enriched sample was transferred to $10 \mathrm{ml}$ of Rappaport-Vassiliadis broth (RV). $1 \mathrm{ml}$ of pre-enriched sample was transferred to $10 \mathrm{ml}$ of tetrathionate broth (TT) and then both media were incubated at $42^{\circ} \mathrm{C}$ for 24 hours. Besides during plating on solid selective media, they were shaken and streaked onto plates of CHROM agar Salmonella Plus medium and Xylose lysine desoxycholate (XLD) agar. Incubation of the samples was carried out at $35^{\circ} \mathrm{C}$ for 24 hours, after the incubation period of the plates, the samples were examined for typical Salmonella colonies.

The isolation of $E$. coli was determined as stated by (FDABAM) (Feng et al., 2011). In this respect, a $25 \mathrm{~g}$ fish sample was transferred in $225 \mathrm{ml}$ of tryptone phosphate (TP) broth and incubated at $44^{\circ} \mathrm{C}$ for $24 \mathrm{~h}$ for the pre-enrichment period. A volume of enriched broth was plated onto eosin-methylene blue (EMB; colonies produce a green metallic sheen) agar and MacConkey agar plates (colonies are brick red). 


\section{Statistical analysis}

Kolmogorov-Smirnov and Shapiro-Wilk normal tests were used to determine the statistical significance of the results of the study. The groups which were normal distribution was used Student-t, and the groups which weren't normal distribution was used Mann-Whitney $U$. Once the results of normal distribution groups were indicated as average \pm standard deviation, abnormal group results were showed as a min-max median. The result of the study was evaluated as $p<0.05$ and the results were considered statistically significant.

\section{RESULTS AND DISCUSSION}

The identification of the color characteristics in the body parts is a determining factor in distinguishing the gilthead sea bream fish grown in different aquaculture habitats from each other.

The skin, operculum, and flesh of color values of gilthead seabream are provided in Figures 2 to 8 . The lightness values $\left(L^{*}\right)$ of the skin of cultured gilthead seabream in net cage ranged from 59.31 to 86.74 and the values of red and yellow color, $a^{*}$ and $b^{*}$, ranged respectively from -0.46 to -1.03 and 4.06 to 0.17 depending on harvesting times. On the other hand the lightness values $\left(L^{*}\right)$ of the skin of cultured gilthead seabream in earthen ponds ranged from 62.63 to 85.91 and the values of red and yellow color, $a^{*}$ and $b^{*}$, ranged respectively from -0.30 to -1.69 and -5.02 to 2.02 in the same harvesting periods. The skin color of the net cage cultured gilthead seabream was darker than those of gilthead sea bream from earthen ponds (Figure 1,2 and 3). Especially, except in April, skin $L^{*}$ values of cultured gilthead seabream from earthen ponds were statistically higher in June, August, October, and December than those of the net cage cultured gilthead seabream. The transparency and the number of rays of the tail fin of gilthead seabream cultured in earthen ponds were more distinctive than those of the gilthead seabream cultured in net cages.

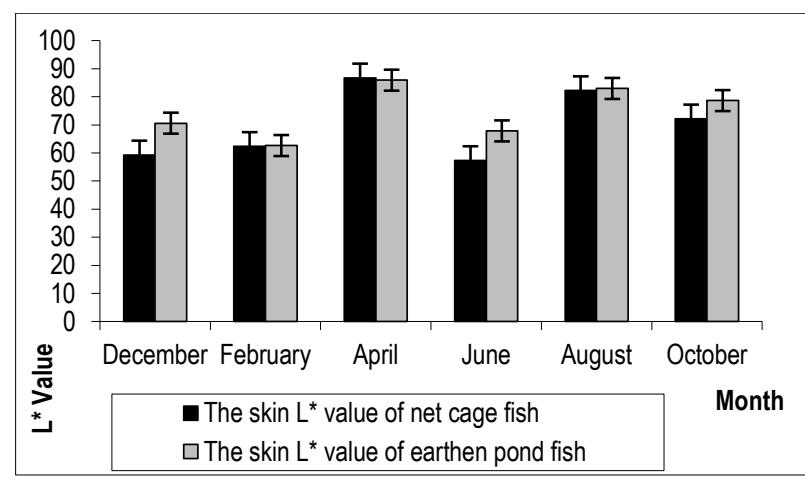

Figure 2. The skin $L^{*}$ values of cultured gilthead seabream.

The $L^{*}$ and $a^{*}$ values of the flesh of cultured gilthead seabream are provided in Figures 4 and 5 . It is determined that the average $L^{*}$ and $a^{*}$ values of the flesh of cultured gilthead seabream in earthen ponds ranged from 45.83 to
81.82 and from -0.52 to 3.63 respectively. On the other hand, the average $L^{*}$ value and $a^{*}$ values of the flesh of cultured gilthead seabream in the net cage ranged from 49.86 to 77.03 and from -0.33 to 4.22 respectively.

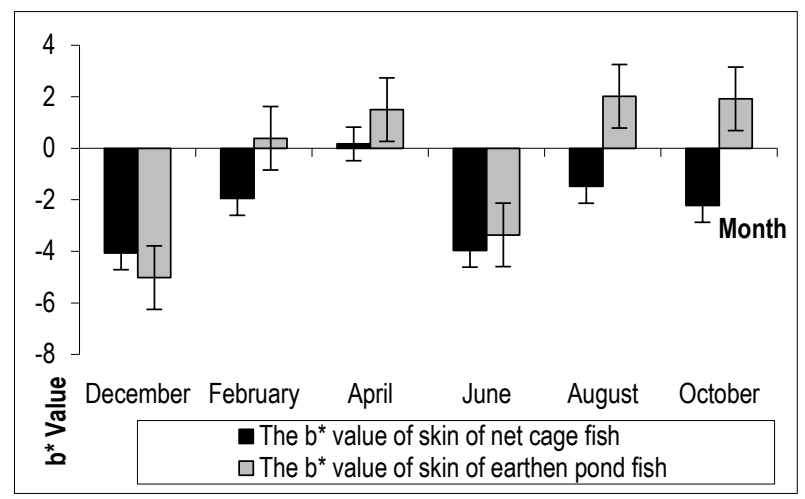

Figure 3. The skin $b^{*}$ values of cultured gilthead seabream

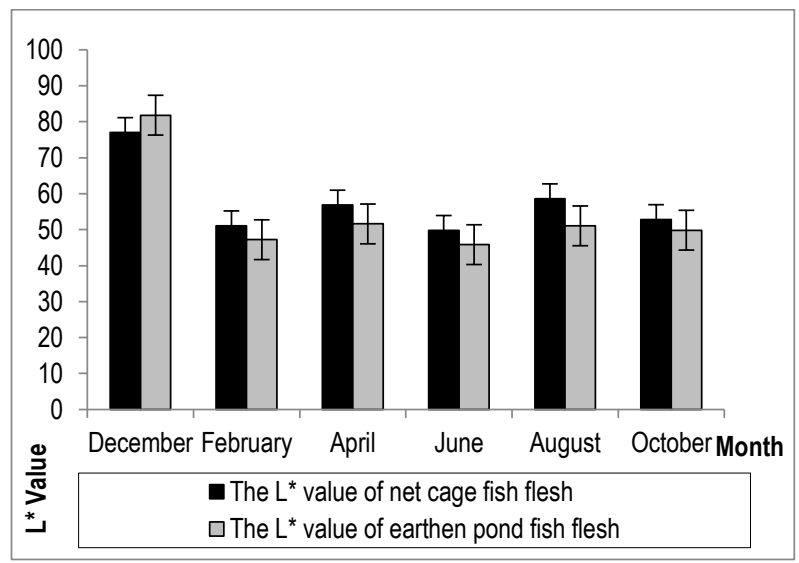

Figure 4. The flesh $L^{*}$ values of cultured gilthead seabream

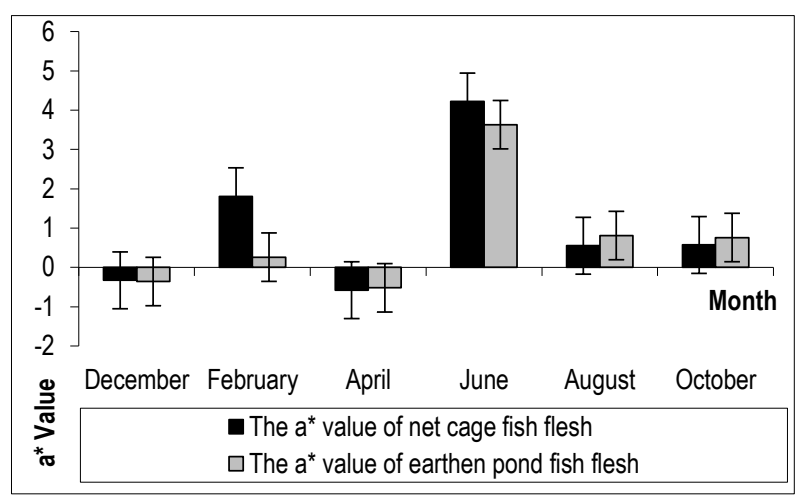

Figure 5. The flesh $a^{*}$ values of cultured gilthead seabream

It was determined that the $L^{*}$ values of the flesh of cultured gilthead seabream in the net cages were brighter than that of the gilthead seabream from earthen ponds only in December whereas during the other months it was exactly the opposite as statistically. However, the $a^{*}$ value of flesh of cultured gilthead seabream in net cages was brighter in February and June whereas, on the contrary, the $a^{*}$ values of flesh of cultured gilthead seabream in earthen ponds were 
brighter in August and October. There was no difference in the $a^{*}$ values of the flesh of cultured gilthead seabream both from the net cage and earthen ponds in December and April $(p>0.05)$.

Cardinal et al. (2011) reported that lightness values of the raw fillet seabream ranged from 41.2 to 43.1 and the values of red and yellow color, $a^{*}$ and $b^{*}$, ranged respectively from1.5 to -0.5 and from -0.4 to -0.04 , according to the period. $A$ significant difference was only observed on the $a^{*}$ parameter of the samples caught in March presenting a slightly less red color. In general, the $a^{*}$ color values of both groups of fish fillets were slightly reddish in December and April whereas it was markedly reddish flesh color in June. These $a^{*}$ color value results are comparable to reported color values by Cardinal et al. (2011). It was determined that the ideal flesh color was similar to that of wild fish in December referring to $L^{*}$ and $a^{*}$ values for both groups of fish fillets. The operculum $L^{*}, a^{*}$, and $b^{*}$ values of cultured gilthead seabream can be seen in Figures 6, 7 and 8. As provided in Figure 7, the $a^{*}$ values of operculum cultured gilthead seabream in earthen ponds ranged from 0.19 to 2.48 . Whereas, it was determined that the redness, $a^{*}$ values of the operculum of cultured gilthead seabream in the net cage were mostly under 1. Statistically, in all harvesting periods operculum, $a^{*}$ value of cultured gilthead seabream in earthen ponds was found more reddish than those of the cultured fish in the net cage $(p<0.05)$. Also in all periods except in December operculum $b^{*}$ values of gilthead sea bream cultured in earthen ponds were yellowish than those of the cultured fish in the net cage $(p<0.05)$.

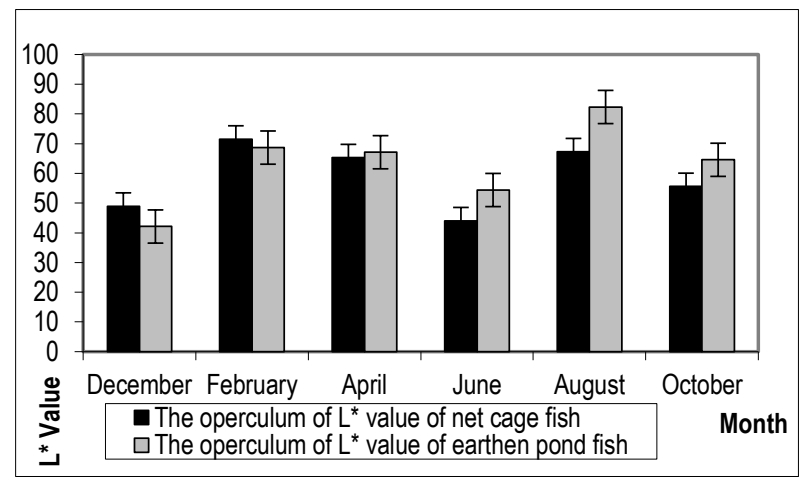

Figure 6. The operculum $L^{*}$ values of cultured gilthead seabream

The wild and cultured seabream could be separated from each other by visual differences such as body shape, color, skin, stamps, teeth, and odor (Grikorakis et al., 2002). Bodycolor differences of cultured gilthead seabream were found significant between cultured in the net cage and earthen ponds $(p<0.05)$. They could be distinguished from each other considering visual characteristics such as skin color, head shape, redness of the operculum, and transparency and color of the tail fin. In this study, the most significant color difference between the two groups of fish was the skin color. The skin $L^{*}$ value of cultured gilthead seabream from earthen ponds was determined brighter than that of the cultured gilthead seabream in the net cage. Moreover, cultured gilthead seabream in earthen ponds had distinct red color on the operculum.

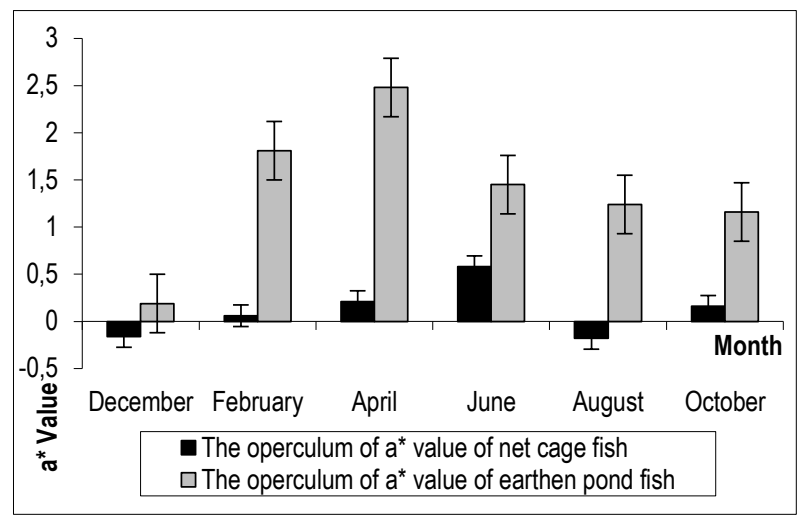

Figure 7. The operculum a* values of cultured gilthead seabream

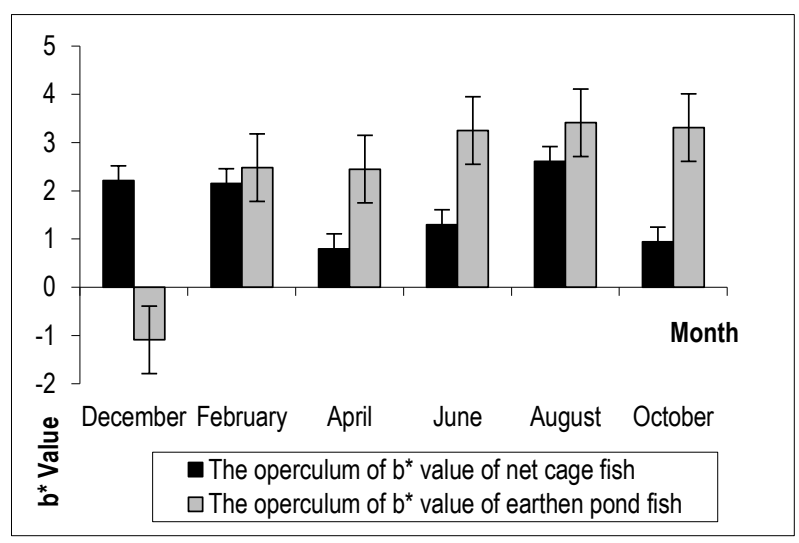

Figure 8. The operculum $b^{*}$ values of cultured gilthead seabream

Besides, gilthead seabream cultured in earthen ponds was separated easily than the other fish samples thanks to the brightness and transparency of the tail fin. While cultured gilthead sea bream in earthen ponds had thinner head just as wild fish, cultured gilthead seabream from net cage had almost a big round-shaped head. Because of the brightness of skin $L^{*}$ value and the redness of $a^{*}$ value on the operculum cultured gilthead seabream in earthen ponds were significantly different than that of the cultured fish in the net cage $(p<0.05)$. Visual characteristics of cultured gilthead seabream in earthen ponds were quite similar to those of the wild gilthead seabream which was also in line with the findings of Grigorakis et. al (2002).

Sensory evaluations of raw and cooked cultured gilthead seabream both from two different habitats are provided in Figures 9 and 10. The quality is generally defined with nutritional, microbiological, biochemical, and physicochemical, but none of these terms are solely enough to define the quality. Sensorial perception and consumer acceptance scores should be considered along with these properties to define the overall quality. The fish quality should be 
maintained seamlessly from fishing to the consumer. The quality index method (QIM) is the commonly used method to determine fish quality lately. The total score represents all quality properties of fish and this score is named as the quality index. For fresh fish, a zero score is given and the score increases when the fish sample gets worse (Nielsen et al., 2002). Papadopoulos et al. (2003) reported that rigor mortis, metallic sheen, and iridescence of the skin, as well as glossy, bright red gills processing seaweedy and shellfish odor, should be considered as attributes of extreme freshness, whereas loss of brilliance and iridescence, fading of skin colors and bleaching of the gills in patches would indicate stale fish. In Figure 9, the sensorial average score of cultured gilthead sea bream in the net cage was 3.3 where cultured gilthead seabream in earthen ponds had a 2.8 average sensorial score. Although the differences weren't statistically meaningful for the sensorial quality of raw fish $(p>0.05)$ however probably these differences could depend on harvesting conditions, feeding regime, sea or freshwater temperature, the effectiveness of cold chain, and transport conditions.

Cardinal et al. (2011) concluded that sensory criteria chosen for seabream cooked fillet related to the appearance, odor, flavor, and texture were identified for odor; global intensity, for appearance, color homogeneity, for texture, firmness, for flavor, global intensity. The taste, odor, and flavor properties of cooked cultured gilthead seabream are shown in Figure 10.

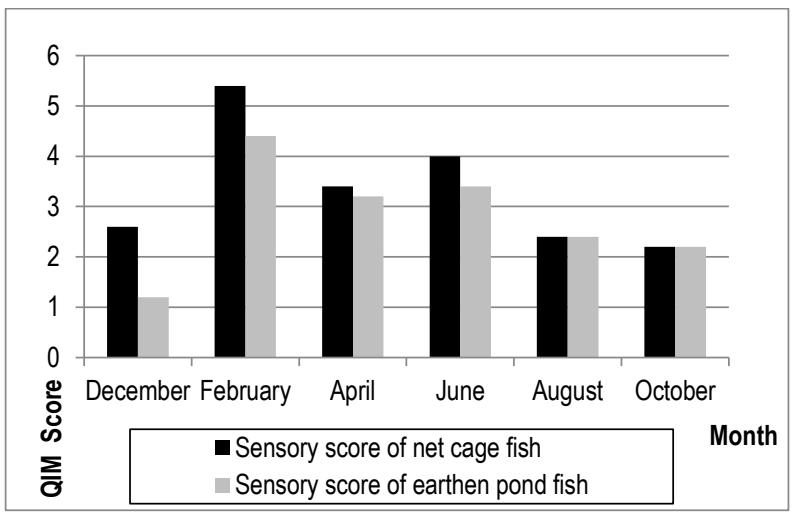

Figure 9. QIM score of raw cultured gilthead seabream. Points represent mean values of ten determinations \pm standard error

The textural properties of cooked cultured gilthead seabream in the net cage were scored the best quality except in February and April by panelists' preferences. On the other hand, in terms of odor characteristics except for December the best quality was determined for cultured gilthead seabream in the net cage. The texture, odor, and flavor of cultured gilthead seabream in the net cage had a great influence on the preferences of the panelists with a higher score in October than cultured fish in earthen ponds.

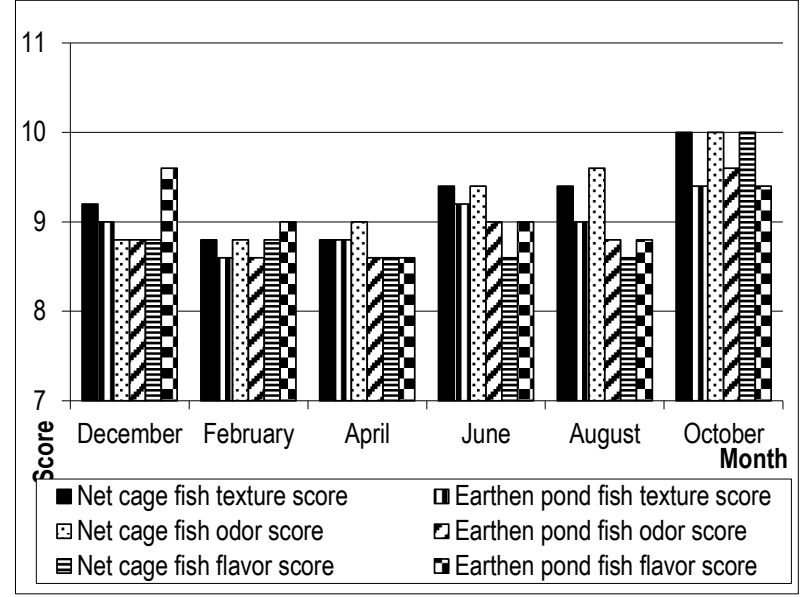

Figure 10. The sensory score of cooked cultured gilthead seabream. Points represent mean values of ten determinations \pm standard error

It was clear that cooked gilthead seabream cultured in earthen ponds had softer flesh tissue than the other fish group. Furthermore, the most preferred group with salty flesh taste cultured gilthead seabream in earthen ponds was noticed. For these reasons, cultured gilthead seabream in earthen ponds were mostly preferred due to the juiciness of fillets by panelists. On the other hand, cultured gilthead seabream in the net cage had harder flesh tissue and less taste than the other fish group. But it was noticed that the cultured gilthead seabream in the net cage showed higher quality through textural and odor parameters. A statistically significant difference couldn't be found between the sensorial properties (texture, odor, and taste) of the two fish groups. The feeding regime is one of the important parameters affecting the cultured fish quality. During feeding periods the digestive tract of the fish contains many bacteria that produce digestive enzymes capable of causing intense postmortem autolysis resulting in strong odors and flavors especially in the abdominal area (Huss, 1995).

Table 1 shows that the total number of mesophilic bacteria in the flesh of gilthead seabream fish was 1.40-3.31 log cfu/g in net cage fish; 1.61-2.99 log cfu/g in the earthen ponds fish. Yeast and mold were determined 2.07-2.90 log $\mathrm{cfu} / \mathrm{g}$ in the net cage fish and 0.74-3.68 log cfu/g in the earthen pond fish. Yeast and mold were determined 2.07-2.90 $\log \mathrm{cfu} / \mathrm{g}$ in the net cage fish and 0.74-3.68 log cfu/g in the earthen pond fish.

There was a difference between the groups in terms of yeast and mold in December, April, and August $(p<0.05)$. The total mesophilic bacteria of gilthead seabream vary in months and groups $(p<0.05)$. In December and February, the number of mesophilic bacteria of cultured fish in the net cage was higher than those of the earthen pond fish. Whereas in April the number of mesophilic bacteria in the earthen pond fish was found to be higher than those of the cultured seabream in the net cage. Attouchi and Sadok (2012) reported that mesophilic bacterial count in fresh farmed seabream was 2.83 
log cfu/g. In our study low initial mesophilic bacterial counts in both cultured fish were found to be similar to those reported in cultured seabream by Attouchi and Sadok (2012). According to ICMSF (1986) that the limit value of mesophilic bacteria for human consumption of fresh fish is $7 \mathrm{log} \mathrm{cfu} / \mathrm{g}$. The total mesophilic bacteria counts of fish groups did not exceed the maximum level for gilthead seabream regardless of the month harvested. Both groups were found to be suitable for human consumption in terms of total mesophilic bacterial load, yeast, and mold in fish meat.

Table 1. Changes in microbiological bacteria count of cultured gilthead seabream

\begin{tabular}{lccc}
\hline Mesophilic & Net cage fish & Earthen pond fish & $p$ \\
\hline December & $3.31 \pm 0.05^{\mathrm{a}}$ & $2.11 \pm 0.06^{\mathrm{b}}$ & 0.001 \\
February & $2.72 \pm 0.06^{\mathrm{a}}$ & $2.59 \pm 0.05^{\mathrm{b}}$ & 0.006 \\
April & $1.40 \pm 0.08^{\mathrm{a}}$ & $1.61 \pm 0.08^{\mathrm{b}}$ & 0.005 \\
June & $2.27 \pm 0.16^{\mathrm{a}}$ & $2.09 \pm 0.07^{\mathrm{a}}$ & 0.065 \\
August & $2.02 \pm 0.07^{\mathrm{a}}$ & $2.20 \pm 0.20^{\mathrm{a}}$ & 0.096 \\
October & $3.14 \pm 0.10^{\mathrm{a}}$ & $2.99 \pm 0.23^{\mathrm{a}}$ & 0.217 \\
& & & \\
\hline Yeast and & Net cage fish & Earthen pond fish & $\boldsymbol{p}$ \\
\hline December & $3.80 \pm 0.08^{\mathrm{a}}$ & $2.42 \pm 0.02^{\mathrm{b}}$ & 0.001 \\
February & $3.12 \pm 0.12^{\mathrm{a}}$ & $2.97 \pm 0.10^{\mathrm{a}}$ & 0.055 \\
April & $1.40 \pm 0.08^{\mathrm{a}}$ & $1.61 \pm 0.08^{\mathrm{b}}$ & 0.005 \\
June & $2.59 \pm 0.14^{\mathrm{a}}$ & $2.40 \pm 0.19^{\mathrm{a}}$ & 0.096 \\
August & $2.31 \pm 0.12^{\mathrm{a}}$ & $2.52 \pm 0.08^{\mathrm{b}}$ & 0.015 \\
October & $3.60 \pm 0.14^{\mathrm{a}}$ & $3.42 \pm 0.20^{\mathrm{a}}$ & 0.140 \\
\hline
\end{tabular}

$\left({ }^{\star}\right)$ a and $b$ determine statistical differences between the two groups during analysis period $(n=5)$

Besides, Salmonella spp. and E. coli are important for food safety. The presence $E$. coli in food indicates fecal contamination in general directly or indirectly depending on the fecal origin. High levels of $E$. coli in food give a general idea that food is produced and stored under inappropriate or inadequate hygiene and sanitation conditions (Temiz, 1998). Salmonella spp. is a disease pathogen and should never be present in food. If sanitary procedures are implemented by good manufacturing practices the production of good eating quality is assured. The pathogenic bacteria release toxins into the substrate, which can be a food product, or the human gastrointestinal system can cause food poisoning (Kanduri and Eckhardt, 2002). According to the microbiological analysis results, Salmonella spp. and E. coli were not detected in any month for two cultured fish samples. The absence of Salmonella spp. and E. coli in any fish groups was an indicator that the consumption of gilthead seabream was suitable for food safety.

The difference in chemical qualities of cultured gilthead seabream in both aquacultural conditions was found to be significant, namely $\mathrm{pH}$, TVB-N, and $\mathrm{NH}_{3}$ values $(\mathrm{p}<0.05)$. (Table 2). Cultured gilthead seabream were found to have $\mathrm{pH}$ values of 6.18 to 6.34 , TVB-N values of 11.40 to 25.29 $\mathrm{mg} / 100 \mathrm{~g}$, and $\mathrm{NH}_{3}$ values of 0.91 to $2.70 \mathrm{mg} / 100 \mathrm{~g}$ in net cage fish. Whereas the cultured gilthead seabream in earthen ponds had $\mathrm{pH}$ values of 6.16 to 6.32 , TVB-N values of 12.80 to $27.85 \mathrm{mg} / 100 \mathrm{~g}$, and $\mathrm{NH}_{3}$ values of 1.01 to $4.32 \mathrm{mg} / 100 \mathrm{~g}$. The small changes in TVB-N values between the flesh of cultured gilthead seabream in two fish groups were statistically significant in December, February, and April $(p<0.05)$. Also, $\mathrm{pH}$ values in the flesh of cultured gilthead seabream between two fish groups were found to be statistically significant only in April $(p<0.05)$. While the TVB-N values of cultured gilthead seabream in the earthen ponds were higher in December and February than that of the cultured gilthead seabream in the net cage. On the other hand, the TVB-N values of cultured gilthead seabream in the net cage were higher amount TVB-N value in April than that of the fishes of the earthen pond.

Table 2. Changes in chemical quality indices of cultured gilthead seabream

\begin{tabular}{lccc}
\hline TVB-N & Net cage fish & Earthen pond fish & $\boldsymbol{p}$ \\
\hline December & $11.40 \pm 0.40^{\mathrm{a}}$ & $12.80 \pm 0.46^{\mathrm{b}}$ & 0.016 \\
February & $25.29 \pm 0.69^{\mathrm{a}}$ & $27.85 \pm 0.40^{\mathrm{b}}$ & 0.005 \\
April & $24.73 \pm 1.11^{\mathrm{a}}$ & $20.84 \pm 1.39^{\mathrm{b}}$ & 0.019 \\
June & $23.03 \pm 1.64^{\mathrm{a}}$ & $23.03 \pm 0.82^{\mathrm{a}}$ & 0.999 \\
August & $20.90 \pm 1.53^{\mathrm{a}}$ & $18.50 \pm 0.79^{\mathrm{a}}$ & 0.073 \\
October & $15.12 \pm 1.00^{\mathrm{a}}$ & $13.61 \pm 0.48^{\mathrm{a}}$ & 0.079
\end{tabular}

\begin{tabular}{lccc}
\hline $\mathrm{NH}_{3}$ analysis & Net cage fish & Earthen pond fish & $p$ \\
\hline December & $1.53 \pm 0.03^{\mathrm{a}}$ & $1.44 \pm 0.04^{\mathrm{b}}$ & 0.037 \\
February & $1.08 \pm 0.01^{\mathrm{a}}$ & $1.80 \pm 0.01^{\mathrm{b}}$ & 0.001 \\
April & $2.61 \pm 0.24^{\mathrm{a}}$ & $4.32 \pm 0.25^{\mathrm{b}}$ & 0.001 \\
June & $0.91 \pm 0.08^{\mathrm{a}}$ & $1.01 \pm 0.07^{\mathrm{a}}$ & 0.189 \\
August & $2.37 \pm 0.06^{\mathrm{a}}$ & $2.16 \pm 0.04^{\mathrm{b}}$ & 0.006 \\
October & $2.70 \pm 0.03^{\mathrm{a}}$ & $2.64 \pm 0.04^{\mathrm{b}}$ & 0.136
\end{tabular}

\begin{tabular}{lccc}
\hline $\mathrm{pH}$ & Net cage fish & Earthen pond fish & $\boldsymbol{p}$ \\
\hline December & $6.25 \pm 0.01 \mathrm{a}$ & $6.25 \pm 0.01 \mathrm{a}$ & 1.000 \\
February & $6.34 \pm 0.04 \mathrm{a}$ & $6.28 \pm 0.02^{\mathrm{a}}$ & 0.084 \\
April & $6.29 \pm 0.07^{\mathrm{a}}$ & $6.16 \pm 0.04^{\mathrm{b}}$ & 0.038 \\
June & $6.18 \pm 0.03^{\mathrm{a}}$ & $6.19 \pm 0.01^{\mathrm{a}}$ & 0.492 \\
August & $6.30 \pm 0.03^{\mathrm{a}}$ & $6.32 \pm 0.04^{\mathrm{a}}$ & 0.566 \\
October & $6.24 \pm 0.02^{\mathrm{a}}$ & $6.23 \pm 0.01^{\mathrm{a}}$ & 0.252 \\
\hline
\end{tabular}

${ }^{*} \mathrm{a}$ and $\mathrm{b}$ determine statistical differences between two groups during analysis period $(n=3)$

The difference between the fish groups was significant due to the ammonia values measured in February, April, August, and December in cultured gilthead seabream $(p<0.05)$.

Together with the increase in TVB-N level in fish meat, the unpleasant taste and odor development in fish characteristically emerge. This is an indication that the chemical quality of the fish flesh has deteriorated beyond the consumable limit value. High ammonia values in fish flesh texture can only be detected when there is significant deterioration.

The total volatile base nitrogen value, which is a sign of fish freshness is a widely used indicator for quality assessment. The European Commission (Council Regulation No. 95/149 EEC of March 1995) reported the acceptable limit 
value for TVB-N as $30-35 \mathrm{mg} / 100 \mathrm{~g}$ in the sensory evaluation of different fish species. In the case of sensory rejection of degraded aquatic products, TVB-N value is supported by the idea that levels of undesirable tastes, which alone are not responsible for seafood spoilage (Dalgaard, 2000). Kyrana et al. (1997) reported that it may be a consequence of the high level of non-proteinaceous nitrogen content in the initial TVB$\mathrm{N}$ level of gilthead seabream flesh. It was determined that the TVB-N value and $\mathrm{NH}_{3}$ value of cultured gilthead seabream from two different habitats in our study were different from each other. The difference is thought to be due to changes in feeding conditions and feed content, or in fish post-mortem conditions. This can lead to loss of quality and limiting the shelf life of fish during cold storage.

\section{CONCLUSION}

As a result, it is thought that the small differences between the total quality scores of the cultured gilthead seabream depend on the harvesting conditions, water temperature, and the effective cold chain conditions. Both groups of fish have features that can appeal to the consumers because of their unique quality characteristics. According to the panelists; soft flesh texture and salty taste can be described as tastier in the earthen ponds culture fish while the hard texture and characteristic aromatic properties of net cage fish can be the reason for consumers' acceptance.

The visual differences between the two cultured fish are distinguished by the color differences in the skin, operculum, head shape, and transparency of rays in the fin tail. It is almost impossible to differentiate the wild gilthead seabream from the cultured gilthead seabream from earthen ponds due to similarities in reddish color on the operculum and light skin color.

There is no microbiological evidence that could negatively affect the consumption of edible fish flesh in terms of total

\section{REFERENCES}

Alpbaz, A. (2005). Çipura Yetiştiriciliği. Sayfa: 225-254. In A. Alpbaz (Ed.), Su Ürünleri Yetişţiriciliği. Alp Yayınları, 548 sayfa, ISBN 975-97056-1-3. Özden Ofset, Çamdibi-Izmir (In Turkish).

Alasalvar, C., Taylor, K.D.A. \& Shahidi, F. (2002a). Comparative quality assessment of cultured and wild sea bream (Sparus aurata) stored in ice. Journal of Agricultural and Food Chemistry, 50, 2039-2045. DOI: 10.1021/jf010769a

Alasalvar, C., Taylor, K.D.A., Öksüz, A., Shahidi, F. \& Alexis, M.(2002b). Comparison of freshness quality of cultured and wild sea bass (Dicentrarchus labrax). JFS: Food Chemistry and Toxicology, 67, 32203226. DOI: 10.1111/j.1365-2621.2002.tb09569.x

Alvarez, A., Garcia, B.G., Garrido, M.D. \& Hernandez, M.D. (2008). The influence of starvation time prior to slaughter on the quality of commercial-sized gilthead seabream (Sparus aurata) during ice storage. Aquaculture, 284, 106-114. DOI: 10.1016/j.aquaculture.2008.07.025

Anonymous (2005). Merck Food Microbiology application page 358. Ed: A.K. Halkman, Başak Matbaaclık Ltd Şti Ankara (In Turkish).

Attouchi, M.\& Sadok, S. (2010). The effect of powdered thyme sprinkling on quality changes of wild and farmed gilthead sea bream fillets stored in ice. Food Chemistry, 119,1527-1534.

DOI: 10.1016/i.foodchem.2009.09.038 bacterial load, yeast, and mold. Furthermore, the absence of Salmonella spp. and E. coli is the indication that fish are suitable for consumption in terms of food safety.

Water quality and aquaculture practices play important roles in determining fish quality. Cultured fish production is not permitted near the Turkish coastline by the Ministry of Food, Agriculture, and Livestock authorities. In Turkey, the cultured fish pass through the HACCP control system before sales, be individually marked, and are sold at retail fish markets. The fish production companies are certified by the authorities and granted a working and aquaculture production permit. The quality of fresh fish from the farm to the fork is regularly checked and reported by Ministerial Inspector. Thus cultured fish are trustable marketed to national and international markets.

\section{ACKNOWLEDGEMENTS}

This study was supported by the Research Foundation of the University of Istanbul (BYP project number: 20886 and UDP project number 43539).

Authors would like to acknowledge Mr. Cengiz Atila President of The Association of Inland Aquaculture Farmers and Producers in Milas Turkey (at the time of the research) and Mrs. Öznur Yıldız Başruh-Quality and Project Manager of Kılıç Holding (at the time of the research) for providing aquacultured gilthead seabream used in this study from the farms of The Association of Inland Aquaculture Farmers and Producers in Milas/Turkey and The Kılıç Deniz Co. in Bodrum/ Turkey.

The microbiological analysis of the study was carried out in the "Aquatic Bacterial Ecology Laboratory". We would like to thank Prof. Dr. Gülşen Altuğ for providing facilities for microbiological analysis. Also, we would like to thank Assoc. Prof. Dr. Bülent Topaloğlu for taking the fish photos.

Attouchi, M. \& Sadok, S. (2012). The effects of essential oils addition on the quality of wild and farmed sea bream (Sparus aurata) stored in Ice. Food Bioprocess Technology, 5, 1803-1816.

Beklevik, G., Polat, A. \& Ozogul, F. (2005). Nutritional value of sea bass (Dicentrarchus labrax) fillets during frozen $\left(-18^{\circ} \mathrm{C}\right)$ storage. Turkish Journal of Veterinary and Animal Sciences, 29, 891-895.

Caggiano, M. (2000). Quality in harvesting and post-harvesting proceduresinfluence on quality. Fish freshness and quality assessment for seabass and seabream. Cahiers Options Méditerranéenns (CIHEAM),1022-1379.

Cardinal, M., Cornet, J., Donnay-Moreno, C., Gouygou, J.P., Bergé, J.P., Rocha, E., Soares, S., Escórcio, C., Borges, P. \& Valente, L.M.P. (2011). Seasonal variation of physical, chemical and sensory characteristics of sea bream (Sparus aurata) reared under intensive conditions in Southern Europe. Food Control, 22, 574-585. DOI: 10.1016/j.foodcont.2010.10.007

Chang, K.L.B., Chang, J., Shiau, C.Y. \& Pan, B.S. (1998). Biochemical, microbiological and sensory changes of sea bass (Lateolabrax japonicus) under partial freezing and refrigerated storage. Journal of Agricultural and Food Chemistry, 46, 682-686. DOI: 10.1021/jf970622c 
Claret, A., Guerrero, L., Gartzia, I., Garcia-Quiroga, M. \& Ginés, R. (2016). Does information affect consumer liking of farmed and wild fish? Aquaculture, 454, 157-162. DOI: 10.1016/j.aquaculture.2015.12.024

Dalgaard, P. (2000). Freshness, Quality and Safety in Seafoods, The National Food Centre, Dunsinea, Castleknock, Dublin 15, Ireland. ISBN 1841701106, pp.1-31.

EU Regulation. (1995). Commission Desicion of 8 March 1995 fixing the total volatile base nitrogen (TVB-N) limit values for certain categories of fishery products and specifying the analysis methods to be used (95/149/EC). Official Journal L097,29/04/1995, p 0084-0087.

Feng, P., Weagant, S.D. \& Jinneman, K. (2011). Diarrheagenic Escherichia coli. Chapter 4A in Bacteriological Analytical Manual (BAM). http://www.fda.gov/food/foodscienceresearch/ laboratorymethods/ucm070080.htm. DOI: 10.1016/j.febslet.2011.06.032

Fishery Statistics (TUIK). (2017). Fishery Statistics. August 2018, Retrieved from https://www.tarim.gov.tr/sgb/Belgeler/SagMenuVeriler/BSGM.pdf. Date of access: September 06,2018.

Grigorakis; K., Alexis, M.N., Taylor, K.D.A. \& Hole, M. (2002). Comparison of wild and cultured gilthead sea bream (Sparus aurata): Composition, appearance and seasonal variations. International Journal of Food Science and Technology, 37, 477-484. DOI: 10.1046/j.1365-2621.2002.00604.x

Grigorakis, K., Taylor, K.D.A. \& Alexis, M.N. (2003a). Organoleptic and volatile aroma compounds comparison of wild and cultured gilthead sea bream (Sparus aurata): Sensory differences and possible chemical basis. Aquaculture, 225, 109-119. DOI: 10.1016/S0044-8486(03)00283-7

Grigorakis, K., Taylor, K.D. \& Alexis, M. (2003b). Seasonal patterns of spoilage of ice-stored cultured gilthead sea bream (Sparus aurata). Food Chemistry, 81, 263-268. DOI: 10.1016/S0308-8146(02)00421-1

Grigorakis, K. (2007). Compositional and organoleptic quality of farmed and wild gilthead sea bream (Sparus aurata) and sea bass (Dicentrarchus labrax) and factors affecting it: a review. Aquaculture, 272, 55-75. DOI: 10.1016/j.aquaculture.2007.04.062

Huidobro, A., Pastor, A. \& Tejada, M. (2000). Quality Index method developed for raw gilthead seabream (Sparus aurata). Journal of Food Science, 65, 1202-1205. DOI: 10.1111/j.1365-2621.2000.tb10265.x

Huss, H.H. (1995). Quality and quality changes in fresh fish. FAO Fisheries Technical Rome. FAO Press, p.348. Retrieved from http://www.fao.org/docrep/V7180E/V7180E00.HTM.

International Commission on Microbiological Specifications for Foods (ICMSF) (1986). International Commission on Microbiological Specification for Foods, Sampling Plans for Fish and Shellfish. In ICMSF, Microorganisms in Foods. Sampling for Microbiological Analysis: Principles and Scientific Applications (2nd. Edition). Vol. 2. University of Toronto Press, Toronto, Canada,181-196.

International Commission on Microbiological specifications for foods (ICMSF) (1998). Potential application of risk assessment techniques to microbiological issues related to international trade in food and food products. Journal of Food Protection, 61, 1075-1086. DOI: 10.4315/0362-028X-61.8.1075

Jha P., Roy R.P. \& Barat S. (2010). Application of sensory and bacterial analysis to assess quality of fish in Siliguri city of West Bengal. Journal of Environmental Biology, 31, 587-594.

Kanduri, L. \& Eckhardt, R.A. (2002). Food Safety in Shrimp Processors, Importers, Exporters and Retailers. Fishing News Books. ISBN 0-85238270-7. DOI: 10.1002/9780470995570
Kılınc, B., Caklı, S., Cadun, A., Dincer, T. \& Tolasa, S. (2007). Comparison of effects of slurry ice and flake ice pretreatments on the quality of aquacultured sea bream (Sparus aurata) and sea bass (Dicentrarchus labrax) stored at $4^{\circ} \mathrm{C}$. Food Chemistry, 104, 1611-1617. DOI: 10.1016/j.foodchem.2007.03.002

Kyrana, V.R., Lougovis, V.P. \& Valsamis, D.S. (1997). Assessment of shelflife of maricultured gilthead sea bream (Sparus aurata) stored in ice. International Journal of Food Science and Technology, 32, 339-347. DOI: 10.1046/j.1365-2621.1997.00408.x

Liston, J. (1980). Microbiology in Fishery Science. In J.J. Connell (Editor), Advances in Fishery Science and Technology. Fishing News Books, Farnham, England, pp. 138-157.

López Ales, J. (2018). Implementation of a gilthead seabream (Sparus aurata L.) breeding program in Murcia. Technical University of Cartagena. Degree in Agricultural Engineering and Biological Systems. pp. 1-64.

Lougovoisa, V.L., Kyranas, E.R. \& Kyrana, V.R. (2003). Comparison of selected methods of assessing freshness quality and remaining storage life of iced gilthead sea bream (Sparus aurata). Food Research International, 36, 551-560. DOI: 10.1016/S0963-9969(02)00220-X

Maturin, L. \& Peeler, J.T. (1998). Bacteriological analytical manual, 6th Edition, Revision A, Chapter 3.

Nielsen, J., Hyldig, G. \& Larsen, E. (2002). Eating quality of fish-A review. Journal of Aquatic Food Product Technology, 11, 125-141. DOI: 10.1300/J030v11n03 10

Obasohan, E.E., Agbonlahor, D.E. \& Obano, E.E. (2010). Water pollution: A review of microbial quality and health concerns of water, sediment and fish in the aquatic ecosystem. African Journal of Biotechnology, 9,423427.

Papadopoulos, V., Chouliara, I., Badeka, A., Savvaidis, I.N. \& Kontominas, M.G. (2003). Effect of gutting on microbiological, chemical and sensory properties of aquacultured sea bass (Dicentrarchus labrax) stored in ice. Food Microbiology, 20,411-420.

Pivarnik, L.F., Thuam, M. \& Ellis, P.C. (1998). Rapid determination of volatile bases in fish by using an ammonia ion-selective electrode. Journal of AOAC International, 81, 1011-22.

Rall, V.L.M., Rall, R., Aragon, L.C. \& Silva, M.G. (2005). Evaluation of three enrichment broths and five plating media for Salmonella detection in poultry. Brazilian Journal of Microbiology, 36, 147-150. DOI: $10.1590 /$ S1517-83822005000200009

Schormüller, J. (1968). Tierische Lebensmittel Eier, Fleisch, Buttermilch. In Handbuch der Lebensmittel Chemie, Band III/2 Teil, 1493-1494. BerlinHeidelberg-New York: Springer- Verlag.

Tagem (2019). Tarımsal Araştırmalar ve Politikalar Genel Müdürlüğü, Su Ürünleri Sektör Politika Belgesi/2019-2023. Ankara/Turkey 146p. Retrieved from

https://www.tarimorman.gov.tr/TAGEM/Menu/28/Yayinlar_veriler Date of access: May 30,2020 (In Turkish).

Temiz, A. (1998). Gıdalarda indikatör mikroorganizmalar. In A. Ünlütürk \& F. Turantaş, (Eds), Gıda Mikrobiyolojisi (pp. 102-605) Mengi Tan Basımevi, Çınarlı-lzmir (In Turkish).

Yıldız, M., Şener, E. \& Timur, M. (2008a). Effects of differences in diet and seasonal changes on the fatty acid composition in fillets from farmed and wild sea bream (Sparus aurata L.) and sea bass (Dicentrarchus labrax L.). International Journal of Food Science and Technology, 43, 853-858. DOI: 10.1111/j.1365-2621.2007.01526.x

Yıldı, M.(2008b). Mineral composition in fillets of sea bass (Dicentrarchus labrax) and sea bream (Sparus aurata): a comparison of cultured and wild fish. Journal of Applied Ichthyology. 24, 589-594. DOI: 10.1111/j.1439-0426.2008.01097.x 